\title{
DOUBLE-CRESTED CORMORANTS EXPAND THEIR BREEDING RANGE ONTO THE BOREAL SHIELD IN SASKATCHEWAN
}

JENNIFER L. DOUCETTE, Department of Biology, University of Regina, Regina, SK; E-mail: <douce2je@uregina.ca>; ALEKSANDRA BUGAJSKI, Department of Biology, University of Regina, Regina, SK; MARK DUFFY, Saskatchewan Ministry of Environment, La Ronge, SK

In Saskatchewan, Double-crested Cormorants (hereafter cormorants) nest in colonies on lakes in the southern Prairie and central Boreal Plain ecozones. The largest known Saskatchewan cormorant colonies (e.g., Primrose Lake, Dore Lake, and Lavallee Lake) are found on highly productive lakes in the Boreal Plain (Fig. 1); however, a previously undocumented large colony (which we describe here) on Egg Lake southwest of La Ronge (see cover photo), is at the northern limit of the Boreal Plain ecozone. In addition, in 2009 we surveyed four breeding colonies of cormorants on Lac La Ronge, which is beyond their historically documented breeding range in Saskatchewan. All colonies are on small islands located some distance from the nearest mainland (Table 1).

Nest counts on Egg Lake were conducted for the first time in 2008 . Using spray paint to delineate small areas for counting, the count revealed a total of 3,856 nests on three small islands in the lake. Approximately 3,000 of those were located on the main nesting island $\left(55^{\circ} 07^{\prime} \mathrm{N}, 105^{\circ} 33^{\prime} \mathrm{W}\right)$, which is very densely populated (see cover photo). This colony was not documented in any of the provincial surveys conducted in 1968 to
1991, or in the 2006 counts. However, cormorants have been observed in the La Ronge area for at least 15 to 20 years (G. Stomp, pers. comm.).

The largest cormorant colony on Lac La Ronge is located on a small granite island in Nut Bay in the western portion of the lake at the transition between the Boreal Plain and Boreal Shield ecozones. There are a number of dead trees on the island and some remaining living vegetation (Fig. 2). This nesting colony first came to our attention (but could have been there longer) in 2007, but since that time cormorants there have not produced any young. In July 2009, we observed 200 nest structures on the island, but no eggs or chicks were present. For comparison, at a well-established colony on Dore Lake $\left(54^{\circ} 46^{\prime} \mathrm{N}, 107^{\circ} 17^{\prime} \mathrm{W}\right)$, cormorants begin incubating eggs in May, and chicks hatch in June (personal observations). Thus, cormorants attempting to nest in Nut Bay were well behind schedule in comparison to other locations at similar latitude. The cause for apparent breeding failure at this site is uncertain.

During the summer of 2008 , two previously unknown smaller colonies were discovered on Lac La Ronge. They 


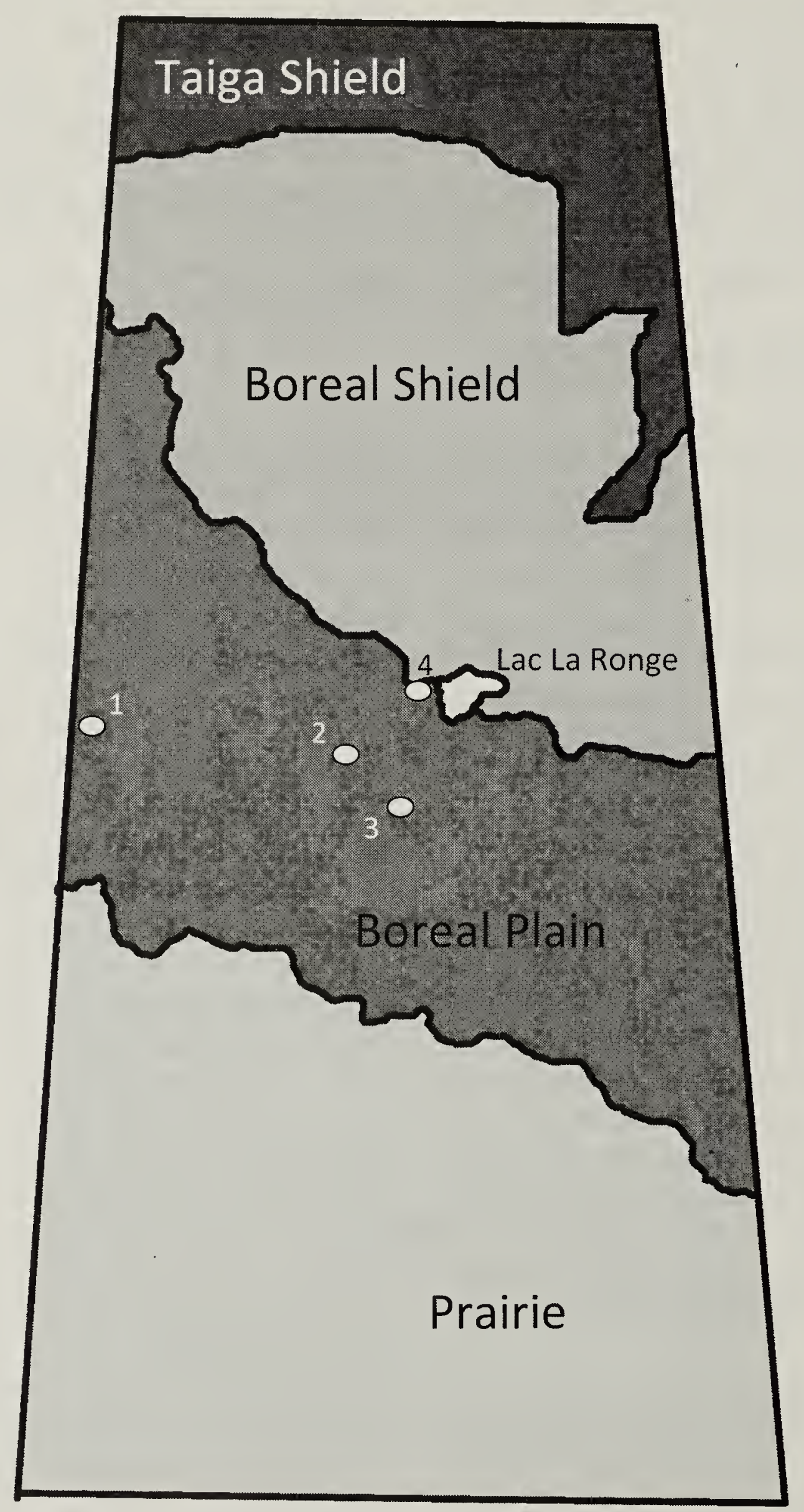

Fig. 1. Saskatchewan is divided into four ecozones. Historically, cormorants have nested in the Prairie and Boreal Plain ecozones, but recently have expanded into the Boreal Shield at Lac La Ronge. Saskatchewan's three largest cormorant colonies at the time of this study were located on the Boreal Plain: Primrose Lake (1), Dore Lake (2), and Lavallee Lake (3). Egg Lake (4), just west of La Ronge, is located at the extreme edge of the Boreal Plain. 
Table 1. New Double-crested Cormorant breeding colonies observed on islands in Lac La Ronge, SK, during July 2009. Nest numbers are estimates and have been rounded to the nearest five.

\begin{tabular}{|l|l|l|}
\hline General Location & Coordinates & No. of nests \\
\hline Nut Bay & $\begin{array}{l}55^{\circ} 10.653 \mathrm{~N} \\
105^{\circ} 11.555 \mathrm{~W}\end{array}$ & 200 \\
\hline $\begin{array}{l}4 \mathrm{~km} \text { east of Long } \\
\text { Island }\end{array}$ & $\begin{array}{l}55^{\circ} 04.680 \mathrm{~N} \\
104^{\circ} 53.825 \mathrm{~W}\end{array}$ & 50 \\
\hline $\begin{array}{l}4 \mathrm{~km} \text { east of Long } \\
\text { Island }\end{array}$ & $\begin{array}{l}55^{\circ} 04.782 \mathrm{~N} \\
104^{\circ} 53.703 \mathrm{~W}\end{array}$ & 175 \\
\hline South of High Island & $\begin{array}{l}55^{\circ} 09.314 \mathrm{~N} \\
105^{\circ} 03.501 \mathrm{~W}\end{array}$ & $\begin{array}{l}\text { Unknown, but } \\
\text { few }\end{array}$ \\
\hline & TOTAL & $\mathbf{> 4 2 5}$ \\
\hline
\end{tabular}

were located on small, granite islands in the central portion of the lake, east of Long Island and approximately $22 \mathrm{~km}$ from the colony in Nut Bay (Fig. 3). The larger island had 175 nests, while the smaller had 50 . Most nests contained eggs in July, and unfledged juvenile birds (Fig. 4) were observed on a subsequent visit in August. The vegetation used to construct nest structures was new and devoid of guano, indicating that these colonies are likely no more than a few years old. A fourth colony was discovered on a rock reef south of High Island in
August 2009. This small colony is located approximately halfway between the Nut Bay and Long Island colonies. Adults were observed on nests, so the island was not approached for a nest count; however, this was a small colony similar in size to the others.

Populations of Double-crested Cormorants are recovering throughout North America after a major decline in productivity in the late $19^{\text {th }}$ and early $20^{\text {th }}$ centuries likely due to human persecution and pesticide contamination (e.g., DDT). ${ }^{1,2}$

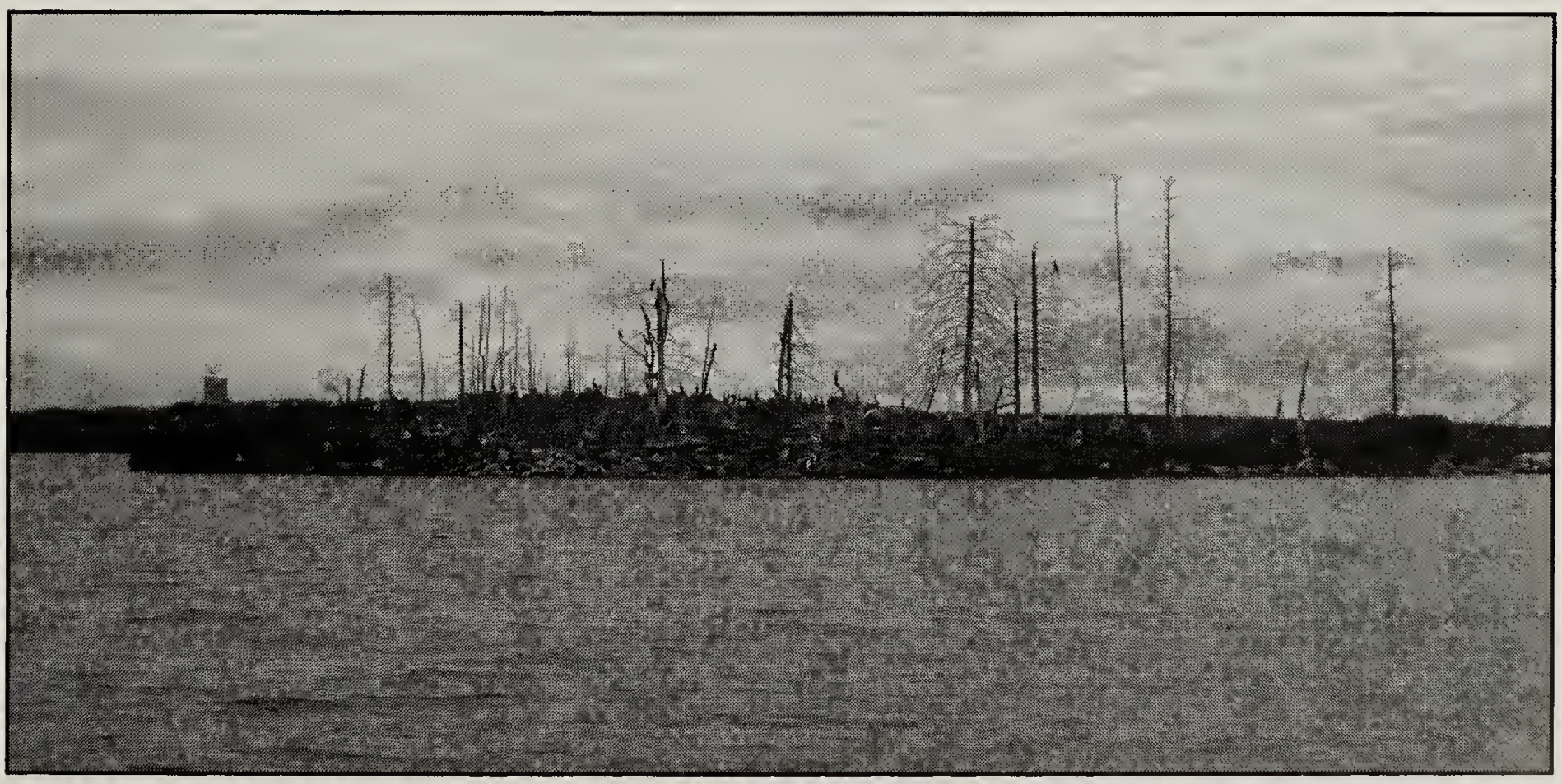

Figure 2. Double-crested Cormorant colony in Nut Bay, Lac La Ronge, SK, is the first documented cormorant colony on Lac La Ronge. Jennifer L. Doucette 


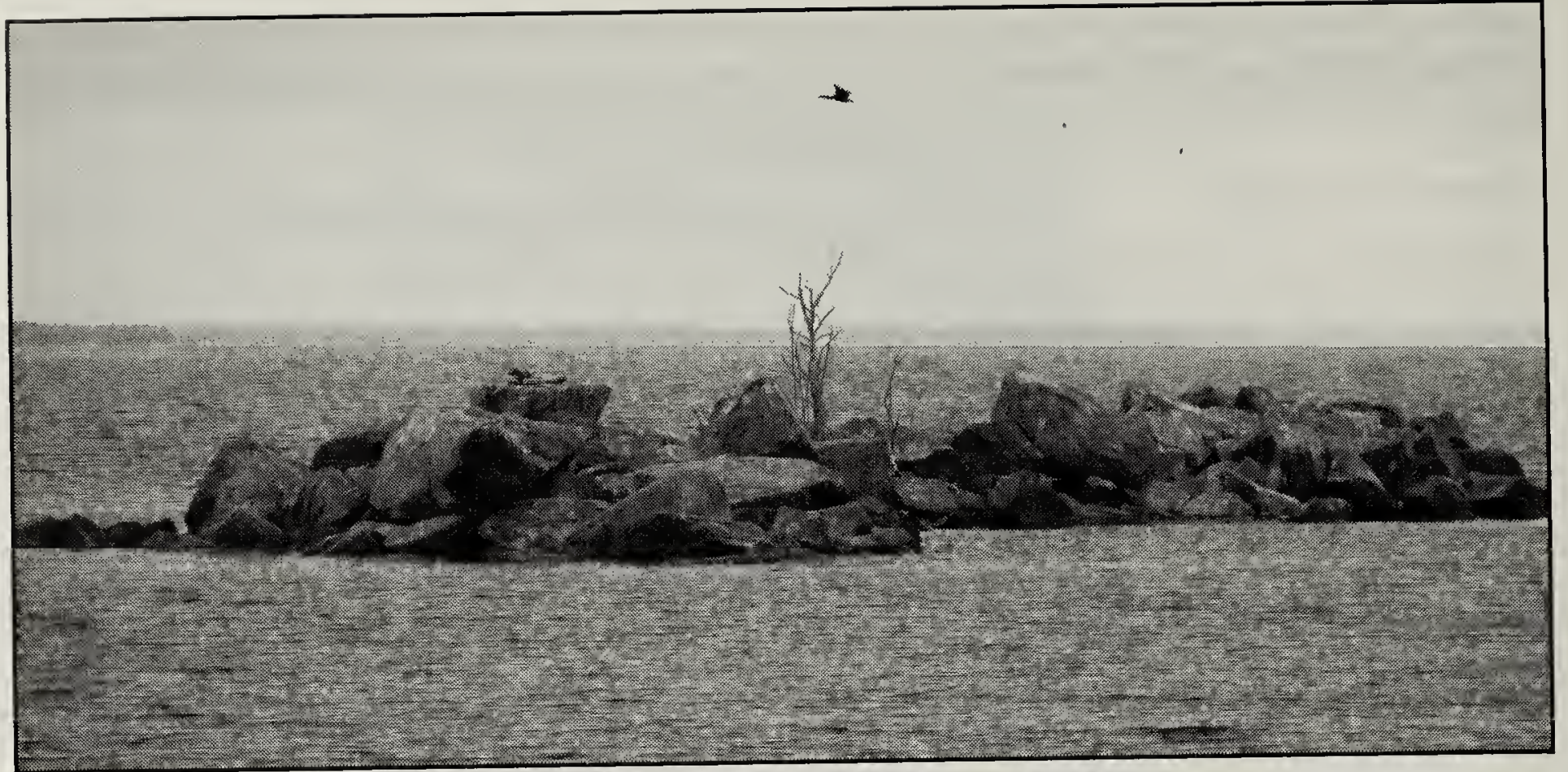

Figure 3. Double-crested Cormorant colony with 50 nests located east of Long Island, Lac La Ronge, SK. The La Ronge cormorant colonies are the first known colonies in the Boreal Shield region of Saskatchewan.

Aleksandra Bugajski

Little is known about cormorant breeding colonies in Saskatchewan before this time, so it is unclear whether cormorant colonies have ever previously existed on the Boreal Shield. The low productivity of northern lakes typically does not support large numbers of avian predators, and no previous records of cormorants breeding on Lac La Ronge exist. The cause of what is likely a recent northern range expansion for these birds is unknown, but it will be important to understand how these novel predators fit into Boreal Shield lake ecosystems.

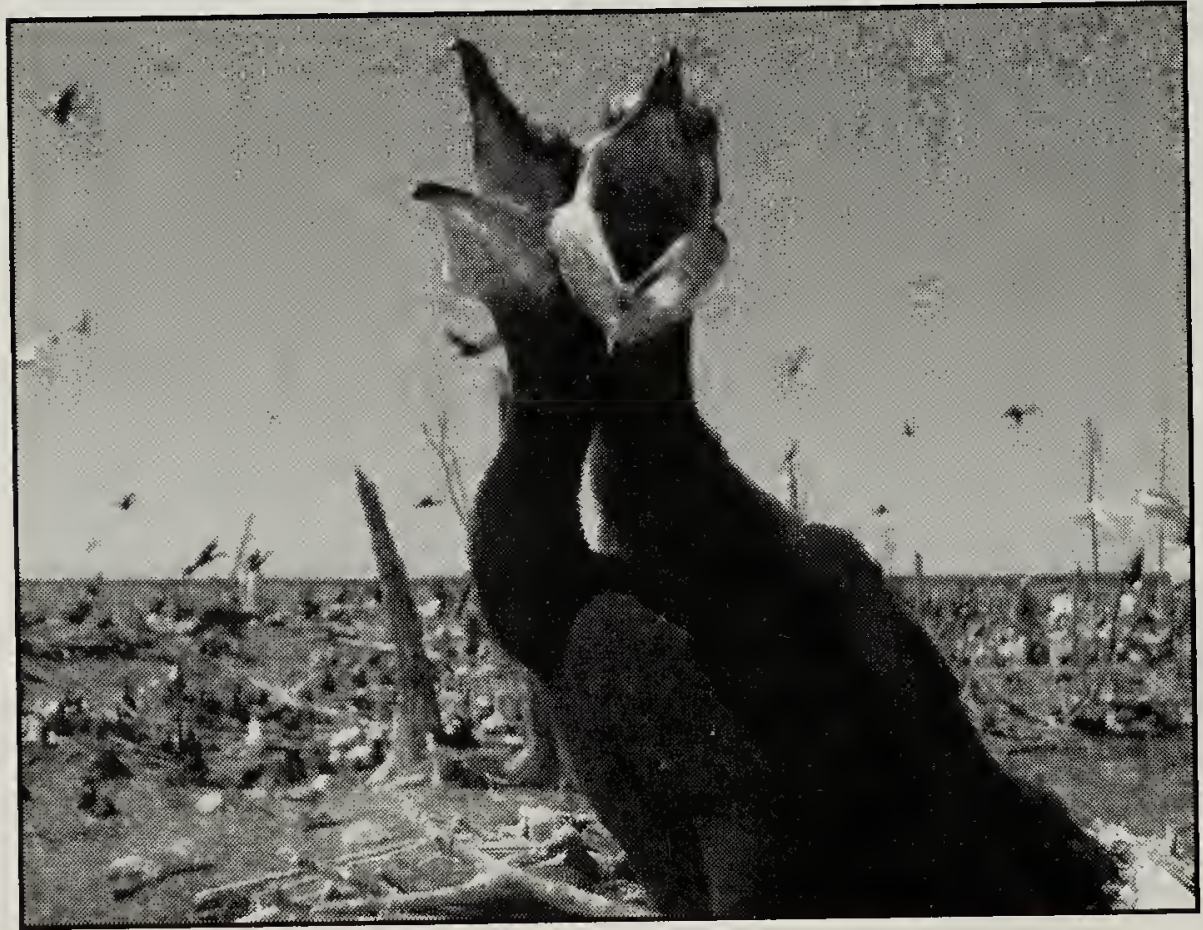

Figure 4. Unfledged juvenile Double-crested Cormorants.

Jennifer L. Doucette

1. WESELOH, D. V., P. J. EWINS, J. STRUGER, P. MINEAU, C. A. BISHOP, S. POSTUPALSKY, and J. P. LUDWIG. 1995. Double-crested cormorants of the Great Lakes: Changes in population size, breeding distribution and reproductive output between 1913 and 1991. Colonial Waterbirds 18 (Special Publication 1):48-59.

2. WIRES, L.R. and F.J. CUTHBERT. 2006. Historic populations of the double-crested cormorant (Phalacrocorax auritus): Implications for conservation and management in the $21^{\text {st }}$ century. Waterbirds 29:9-37. 